\title{
Non-suicidal self-injury: an unexplored cause of dental trauma
}

\author{
Sribala Naga Gantha, ${ }_{1}^{1}$ Mahesh Chinta, ${ }^{1}$ Pratej Kiran Kanumuri, ${ }^{2}$ Charishma Birra ${ }^{3}$
}

${ }^{1}$ Department of Pedodontics and Preventive Dentistry, Panineeya Mahavidyalaya Institute of Dental Sciences and Research Centre, Hyderabad, Andhra Pradesh, India

${ }^{2}$ Panineeya Institute of Dental Sciences and Hospital, Hyderabad, Telangana, India ${ }^{3}$ Saint Joseph's Dental College, Eluru-Duggirala, Andhra Pradesh, India

Correspondence to Dr Pratej Kiran Kanumuri, pratejkiran@gmail.com

Accepted 23 March 2017

\section{DESCRIPTION}

Non-suicidal self-injury (NSSI) is defined as intentionally causing destruction to one's skin or body without an intent to die. ${ }^{1}$ NSSI is a behaviour uncommonly noticed in adolescents and young adults. The prevalence rate of NSSI varying between $7 \%$ and $46.5 \%$ with $13-15$ years is the distinctive age for adolescents. ${ }^{2}$ Most common form of NSSI are skin cutting, carving, scratching, wound picking and self-hitting. Individuals engaged in any of these activities were found to develop suicidal tendencies. Most common site of occurrence of these injuries is head, specifically oral and perioral tissues, hands and neck. ${ }^{3}$ The case presented here is a rare entity of NSSI presenting as dental trauma.

A 14-year-old boy reported to the Department of Paediatric Dentistry with his parents, with a chief complaint of broken upper front teeth. When history of trauma was discussed, parents revealed that the boy himself broke his teeth by hitting with hammer, which was disclosed to his parents after few days. After which he developed sensitivity. The reason told by his parents was that the child was constantly bullied in the school by his peers due to the abnormal size of his teeth. This was also brought to the notice of his parents at home many times, but they ignored it. When history of similar such self-inflicting injuries were inquired, parents responded negatively. But they revealed that since a year, the child was avoiding all social gatherings and would not talk to his friends. Intellectual age of the

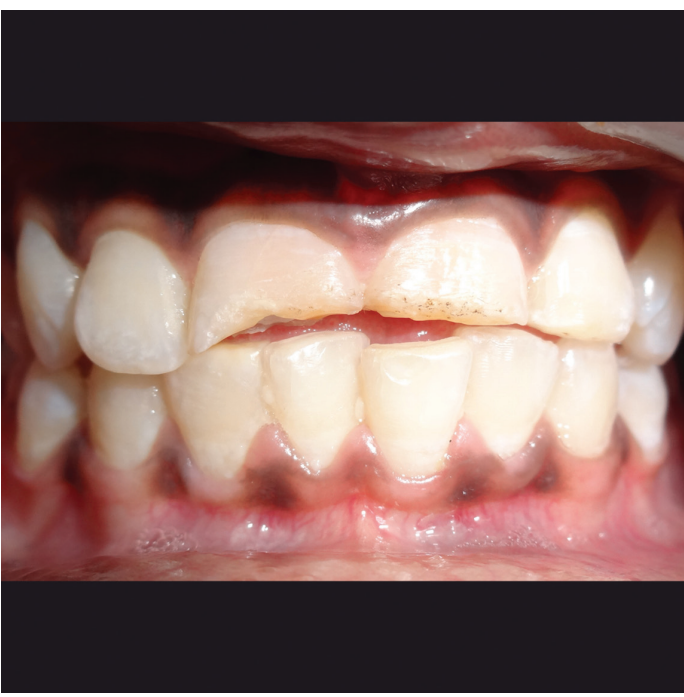

Figure 1 Preoperative photograph showing Ellis class II fracture involving 11 and 21 due to non-suicidal selfinjury.

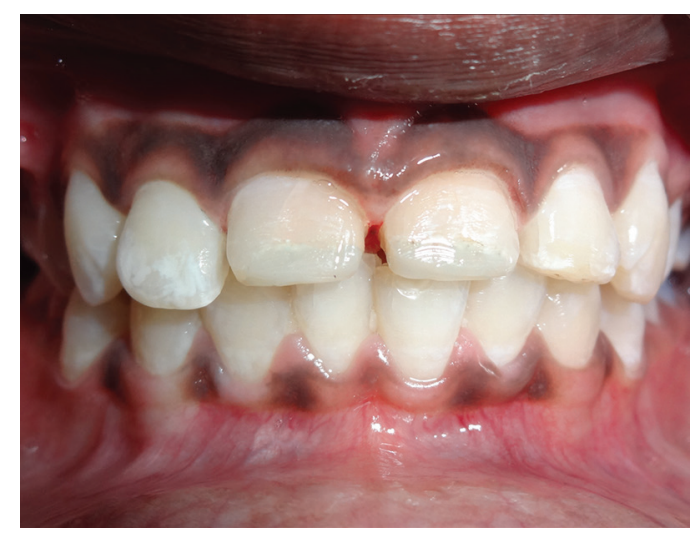

Figure 2 Postoperative photograph showing composite restoration of fractured teeth 11 and 21 .

child corresponds to his school grade. No significantly contributing medical history was reported, and all milestones were age appropriate. Parents also disclosed about the aggressive behaviour of the child in school often to some incidents, which was complained by his teachers. With this strange information, a provisional diagnosis of NSSI was made. Oral self-injury may be classified as functional and organic. In cases of organic origin, individuals inflict the injury unconsciously in a compulsive manner. Functional injury is a method of manipulation to seek help or to exhibit desired behaviour. ${ }^{3}$ This case can be categorised as functional self-inflicting injury. In order to confirm NSSI, his psychological status was assessed by NSSI assessment tool (NSSI AT) ${ }^{4}$ and the inference of the NSSI AT was that child tried to break his teeth to deal with frustration. Because, despite informing parents about the bullying in school they ignored it and many times in the past he felt the same but never attempted any injury. Patient revealed that he felt relief after the injury.

On intraoral examination, there is Ellis class II fracture involving 11 and 21 (Federation Dentaire Internationale System) without any trauma to the surrounding structures (figure 1). It was associated with only sensitivity. Composite restoration was done, teeth were contoured to the shape desired by the patient and thus could satisfy the estheticaesthetic concern (figure 2). The child was called for regular check-ups to check the vitality of teeth and was also referred to a psychiatrist for further evaluation and counselling.

Several case reports in the literature regarding NSSI were observed in individuals with medical history or with developmental disorders. This is one such rare case report where NSSI was observed in 
a normal healthy individual due to prolonged emotional stress. Dental trauma should be carefully evaluated for the presence of any psychological reason associated, before it causes behavioural issues, because prevention is always better than cure.

\section{Learning points}

- Non-suicidal self-injury (NSSI) may be a possible aetiological factor for dental trauma in adolescents.

- Skin cutting, carving, scratching, wound picking and selfhitting are the most common forms of NSSI.

- Some non-suicidal psychological traits when detected at early age can be managed very efficiently with counselingcounselling.

Contributors MC done the case report. SNG, PKK and CB prepared the manuscript.
Competing interests None declared.

Patient consent Guardian consent obtained.

Provenance and peer review Not commissioned; externally peer reviewed.

(c) BMJ Publishing Group Ltd (unless otherwise stated in the text of the article) 2017. All rights reserved. No commercial use is permitted unless otherwise expressly granted.

\section{REFERENCES}

1 Nock MK, Favazza A. Non-suicidal self-injury: definition and classification. Nock MK, ed. Understanding non-suicidal self-injury: origins, assessment, and treatment. Washington, DC: American Psychological Association, 2009:9-18.

2 Kerr PL, Muehlenkamp JJ, Turner JM. Nonsuicidal self-injury: a review of current research for family medicine and primary care physicians. J Am Board Fam Med 2010;23:240-59.

3 Limeres J, Feijoo JF, Baluja F, et al. Oral self-injury: an update. Dent Traumatol 2013;29:8-14.

4 Whitlock JL, Exner-Cortens D, Purington A. Validity and reliability of the non-suicidal self-injury assessment test (NSSI-AT) 2007. Cornell research program on self injurius behaviours in adolescents and young adults. http://www.selfinjury.bctr. cornell.edu/ (accessed May 2017).

Copyright 2017 BMJ Publishing Group. All rights reserved. For permission to reuse any of this content visit

http://group.bmj.com/group/rights-licensing/permissions.

BMJ Case Report Fellows may re-use this article for personal use and teaching without any further permission.

Become a Fellow of BMJ Case Reports today and you can:

- Submit as many cases as you like

- Enjoy fast sympathetic peer review and rapid publication of accepted articles

- Access all the published articles

Re-use any of the published material for personal use and teaching without further permission

For information on Institutional Fellowships contact consortiasales@bmjgroup.com

Visit casereports.bmj.com for more articles like this and to become a Fellow 